\title{
Sabellaria spinulosa (Polychaeta, Annelida) reefs in the Mediterranean Sea: Habitat mapping, dynamics and associated fauna for conservation management
}

\author{
Maria Flavia Gravina ${ }^{a},{ }^{*}$, Frine Cardone ${ }^{b}$, Andrea Bonifazi ${ }^{a}$, Marta Simona Bertrandino ${ }^{b}$, \\ Giovanni Chimienti ${ }^{\mathrm{b}}$, Caterina Longo ${ }^{\mathrm{b}}$, Carlotta Nonnis Marzano ${ }^{\mathrm{b}}$, Massimo Moretti ${ }^{\mathrm{c}}$, \\ Stefania Lisco ${ }^{\mathrm{c}}$, Vincenzo Moretti ${ }^{\mathrm{e}}$, Giuseppe Corriero ${ }^{\mathrm{b}}$, Adriana Giangrande ${ }^{\mathrm{d}}$ \\ a Dipartimento di Biologia, Università di Roma "Tor Vergata", Via della Ricerca Scientifica s.n.c., CoNISMA Unit 00133 Roma, Italy \\ b Dipartimento di Biologia, Università di Bari, CoNISMA Unit, Via Orabona 4, 70124 Bari, Italy \\ ${ }^{\mathrm{c}}$ Dipartimento di Scienze della Terra e Geoambientali, Università di Bari, Via Orabona 4, 70124 Bari, Italy \\ d Dipartimento di Scienze e Tecnologie Biologiche ed Ambientali, Università del Salento, CoNISMA Unit, Via Provinciale Lecce-Monteroni, 73100 Lecce, Italy \\ ${ }^{\mathrm{e}}$ Regione Puglia, Servizio Ecologia - Ufficio VIA, Bari, Italy
}

\section{A R T I C L E I N F O}

\section{Article history:}

Received 24 May 2017

Received in revised form

12 October 2017

Accepted 12 November 2017

Available online 13 November 2017

\section{Keywords:}

Benthic invertebrate community

Mediterranean biodiversity

Coastal

Engineering species

Polychaetes

Littoral reef

\begin{abstract}
A B S T R A C T
Bio-constructions by Sabellaria worms play a key functional role in the coastal ecosystems being an engineer organism and for this reason are the object of protection. The most widespread reef building species along Atlantic and Mediterranean coasts is S. alveolata (L.), while the aggregations of S. spinulosa are typically limited to the North Sea coasts. This paper constitutes the first detailed description of unusual large S. spinulosa reefs in the Mediterranean Sea. Defining current health status and evaluating the most important threats and impacts is essential to address conservation needs and design management plans for these large biogenic structures. Present knowledge on Mediterranean reefs of S. alveolata is fragmentary compared to Northeast Atlantic reefs, and concerning S. spinulosa, this paper represents a focal point in the knowledge on Mediterranean reefs of this species. A one-year study on temporal changes in reef structure and associated fauna is reported. The annual cycle of S. spinulosa reef shows a spawning event in winter-early spring, a period of growth and tubes aggregation from springearly summer to autumn and a degeneration phase in winter. The variations exhibited in density of the worm aggregation and the changes in the reef elevation highlight a decline and regeneration of the structure over a year. The many ecological roles of the $S$. spinulosa reef were mainly in providing a diversity of microhabitats hosting hard and sandy bottom species, sheltering rare species, and producing biogenic structures able to provide coastal protection. The Mediterranean S. spinulosa reef does not shelter a distinctive associated fauna; however the richness in species composition underscores the importance of the reef as a biodiversity hot-spot. Finally, the roles of the biogenic formations and their important biotic and physical dynamics support the adoption of strategies for conservation of Mediterranean S.spinulosa reefs, according to the aims of the Habitat Directive.
\end{abstract}

() 2017 Elsevier Ltd. All rights reserved.

\section{Introduction}

In temperate marine coastal regions some polychaetes of the Sabellariidae family build large and durable aggregate structures that may cover several square kilometers of sandflats (Gruet and Bodeur, 1997). They build tubes from sand and shell fragments

\footnotetext{
* Corresponding author.

E-mail address: maria.flavia.gravina@uniroma2.it (M.F. Gravina).
}

held together with cement and form dense aggregations on sandy and mixed substrata and on bedrock; these aggregations can spread over several $\mathrm{km}^{2}$ on sand flats. Such aggregations can be formed relatively quickly and may take the form of sheets, hummocks and reefs, as well as evolving from globular formations into reef platforms. The reefs undergo a natural cycle with settlement, growth and destruction phases, as a result of development and decay due to both physical and biological factors (Gruet, 1986). Therefore, bio-constructions may persist in an area for many years 
even though individual clumps may regularly form and disintegrate.

Sabellaria reefs play an important key functional role in shallow coastal areas, since they contribute to physical and biological processes by stabilizing the substrate and trapping sediment, by mitigating coastal erosion (Naylor and Viles, 2000; Hendrick and Foster-Smith, 2006; Desroy et al., 2011) and by providing an array of microhabitats suitable for the settlement of benthic organisms and so increasing the coastal biodiversity (Dubois et al., 2002, 2006; Cole and Chapman, 2007). Sabellaria reefs are also highly vulnerable structures subject to various direct and indirect human pressures. Both fishing and the trampling associated with intensive mussel cultivations are largely damaging these fragile habitats and alien species also have a potentially negative impact (Dubois et al., 2002, 2006; Desroy et al., 2011; Plicanti et al., 2016). Therefore such worm reefs have been identified as being of rare biological and heritage sites and proposed for conservation by the IUCN (International Union for Conservation of Nature for Protection).

The reef building species most widespread along European Atlantic and Mediterranean coasts is S. alveolata (L.) whose bioconstructions occur not only in the low intertidal zone in NorthEastern Atlantic (Mettam, 1992; Holt et al., 1998; Fournier, 2013), but also in the midlittoral-upper-infralittoral zone in the Mediterranean Sea (Molinier and Picard, 1953; Giordani Soika, 1956; Taramelli Rivosecchi, 1961; Porras et al., 1996; Delbono et al., 2003; La Porta and Nicoletti, 2009; Schimmenti et al., 2016). The congeneric S. spinulosa Leuckart is a smaller species that in most parts of its geographic range is solitary or found in small groups, encrusting pebbles, shells, kelp holdfasts and bedrock (Gruet, 1986; Gibb et al., 2014). Under favorable conditions, however, dense aggregations may be found, forming reefs up to several $\mathrm{cm}$ high. Such aggregations are reported to occur at various locations around the British Isles (Hendrick and Foster-Smith, 2006; Limpenny et al., 2010). To date, in the Mediterranean, S. spinulosa has mainly been found together with $S$. alveolata, but always at low densities and without forming reefs (Nicoletti et al., 2001).

This interesting habitat has been the object of several investigations related to conservation. The protection for Atlantic Sabellaria reefs has been instituted by several regulations and policies regulating discharges into the sea and setting targets on quality standards for marine waters. Moreover, regulation of motorized traffic on the reefs and promotion of sustainable gleaning techniques on the reefs and their vicinity has also been passed. Such reefs are listed as a threatened and declining habitat under the Convention for the Protection of the Marine Environment of the North-East Atlantic (OSPAR, 2008).

Although Mediterranean polychaetes reefs have also been inserted in the 'European Red list of habitats' (Gubbay et al., 2016), present knowledge of Mediterranean polychaete reefs ( $S$. alveolata included) remains scarce. Very little information is available about their occurrence and area of occupancy. Also there have been no quantitative analyses to assess their current health status and to define their dynamics, let alone evaluate the most important threats and impacts. Such an omission makes it not possible to address the conservation needs or suggest management practices and policy and protection procedures of such bioconstructions. The most severe scenario involves $S$. spinulosa, whose reef presence until recently remained undetected. As a result, available data are insufficient to properly assess the habitat according to any of the Red list criteria: in contrast to the North Atlantic scenario, the Mediterranean polychaete reefs are listed as 'Data Deficient' (Gubbay et al., 2016).

Determining the distribution of the Sabellaria reef and characterizing its geomorphological and biological aspects are needed in order to consider pressures and develop ecosystem-based management. The main aims of present study have been as follows: a) to map S. spinulosa reefs along the Adriatic Apulian coast; b) to analyze the structural changes of this biogenic structure over time at a selected site (namely Torre Mileto), and c) to investigate the associated fauna of this reef in order to define assemblages linked to the different phases of the reef development.

\section{Methods}

\subsection{Study area and habitat mapping}

The study area is located along the southern Adriatic coast of Apulia in the northern littoral sector of the Gargano promontory, between Marina di Chieuti $\left(41^{\circ} 55^{\prime} 16.25^{\prime \prime} \mathrm{N}-15^{\circ} 09^{\prime} 32.32^{\prime \prime} \mathrm{E}\right)$ and Manfredonia $\left(41^{\circ} 37^{\prime} 51.85^{\prime \prime} \mathrm{N}-15^{\circ} 54^{\prime} 55.80^{\prime \prime} \mathrm{E}\right)$, for a total of approx. $135 \mathrm{~km}$ of coast line (Fig. 1a). Here large sandy beaches alternate with narrow pocket beaches: they are wave-dominated and are mainly fed by terrigenous materials coming from the delta of the Fortore River, the local long-shore drift being directed from west to east (Simeoni et al., 1999). Beach sand composition is always a siliciclastic-calciclastic mix, this being the result of the erosion of older chain, foredeep and foreland sedimentary outcrops in adjacent continental settings (Moretti et al., 2010; Gallicchio et al., 2014; Gioia et al., 2014). In order to produce a fine scale mapping of Sabellaria occurrence, the location and spatial distribution of the bioconstructions built by these worms were investigated during the spring-summer 2012. The activity was carried out by direct observation of the seabed where the Sabellaria formations could be present, at the depth range of $0-5 \mathrm{~m}$. The observation took place on board a small boat with reduced draft, using a mirror for underwater vision, and, when necessary, through snorkeling and scuba diving. In particular, observations were made along a couple of transects, perpendicular to the coast line, each located in west, central and east sectors, covered by two scuba-diving and in the entire investigated area (according to Lisco et al., 2017). The bioconstruction have been observed and the reliefs have been georeferenced by GPS Garmin eTrex 10. To support observations, a digital camera was used, at waypoints logged with the GPS, to capture visual data of the state of the $S$. spinulosa reefs.

\subsection{Field survey and laboratory analysis}

\subsubsection{Field survey and sampling design}

The Sabellaria reef was surveyed between 1.5 and $2.2 \mathrm{~m}$ of depth during four sampling campaigns in April 2012, October 2012, February 2013 and June 2013 at the site Torre Mileto (Northern coast of Gargano, Apulia). Underwater direct observations and photos were obtained by scuba-diving, in order to detect the reef morphological features over time and to inspect possible phases of growth and destruction. The sampling design included nine random replicates (3 replicates $\mathrm{x} 3$ sites inspected) collected during each sampling occasion where the reef is thicker (Fig. 1b); here the reef thickness was measured and samples were taken, both for Sabellaria tube measurement and for the analysis of the associated fauna.

Reef thickness was measured by scuba-divers equipped with a fine metric pole driven into the biogenic structure, taking into consideration the mean value of two measurements (three replicates for each site). Samples for the study of the associated fauna of the bioconstruction were collected by scuba-diving, using a manual corer $15 \times 15 \mathrm{~cm}$ wide and $15 \mathrm{~cm}$ long.

\subsubsection{Laboratory analysis}

In the laboratory, such samples were impregnated with low viscosity epoxy resin in order to preserve the original framework of the tube aggregation. Thin transverse sections $(30 \mu \mathrm{m})$ of the 


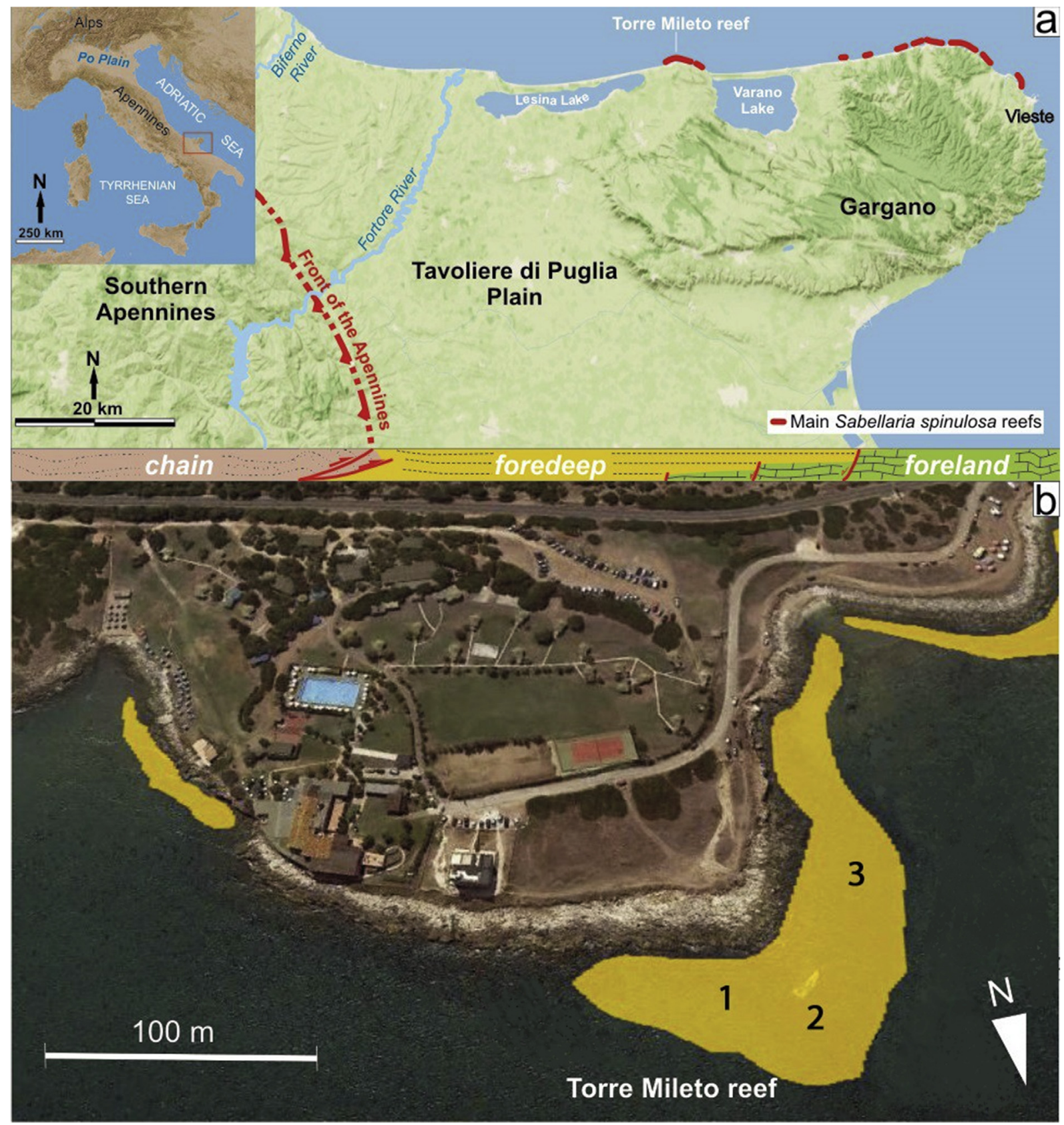

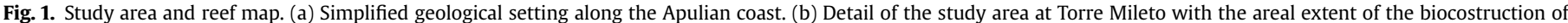
Sabellaria spinulosa (about $10.000 \mathrm{~m}^{2}$ ) and the indication of the sampling locations numbered 1, 2, 3 .

samples were cut, and high-resolution photos were obtained with a scanner. From each photo, detailed morphological features consisting of the density and diameters of Sabellaria tubes were then measured.

Samples for the study of the macrofauna were obtained through a $500 \mu \mathrm{m}$ mesh, fixed in $4 \%$ buffered formalin and preserved in $70 \%$ ethanol; then they were sorted, animals being identified at the highest taxonomic separation (species where possible) and counted. The volumes collected were selected according to the best cost/ accuracy compromise, as reported by Gruet (1971).

\subsection{Data analysis}

Thematic maps to display the distribution and entity of the concretions of S. spinulosa were created using ArcGIS 10 software. The density and the diameters of Sabellaria tubes were evaluated for each location and date by using Image on macro-photos and digitized thin sections as the number of unfilled tubes per unit area of $35 \mathrm{~cm}^{2}$. The diameter of the Sabellaria tubes was measured with ImageJ, considering the maximum dimension of sub-circular and elliptical sections of tubes. In all 28 images were obtained and analyzed for each sample.

For total macrobenthos, biotic parameters, including species richness $(\mathrm{S})$, abundance of macrobenthic fauna $(\mathrm{N})$ and number of individuals of $S$. spinulosa, were computed in order to describe synthetically the changes in the community structure of the associated fauna and were then compared using the ANOVA, the goal being to test the null hypothesis of no differences among times. 
Among multivariate methods, the ordination technique of nonmetric Multidimensional Scaling (nMDS), based on Bray-Curtis (dis)similarity matrices, was performed, using faunal abundance data, in order to compare benthic communities at the four different sampling occasions. In addition, the SIMPER procedure, based on Bray-Curtis matrix (Clarke and Warwick, 2001), was carried out to identify the species which characterize the macrofaunal assemblages at different sampling occasions and which contribute most (cut-off 90\%) to the dissimilarities among samples. In the multivariate analyses, data were square-root transformed. The test ANOSIM was also performed in order to investigate similarity among the macrofaunal samples. Moreover, the biotic parameters, species richness abundance, diversity, and eveness of the associate fauna, were related with the development status of the reef (measured as density of Sabellaria individuals and diameter of the tubes) by the simple regression analysis. Data analyses were performed using PAST (Hammer et al., 2001).

\section{Results}

\subsection{Distribution of Sabellaria reefs}

Bioconstructions of Sabellaria spinulosa were discontinuously detected between Torre Mileto $\left(41^{\circ} 55^{\prime} 45.3^{\prime \prime} \mathrm{N}-15^{\circ} 37^{\prime} 12.37^{\prime \prime} \mathrm{E}\right)$ and Vieste $\left(41^{\circ} 52^{\prime} 54.20^{\prime \prime} \mathrm{N}-16^{\circ} 10^{\prime} 27.07^{\prime \prime} \mathrm{E}\right)$, along approx. $34 \mathrm{~km}$ of a coastline (Fig. 1a). All observed bioconstructions were developed on a coherent substrate, mainly represented by rocky surfaces of variable dimensions, surrounded by sandy substrate. The extent and type of formations, however, had different characteristics in various sites where they were observed. In the length of coast between Torre Mileto and the mouth of Capoiale, bioconstructions were mainly developed in a continuous form, with interposed isolated formations, assuming the status of true reefs (Fig. 1b). Continuing east and beyond the mouth of Capoiale, there was no significant presence of bioconstructions of S. spinulosa except in the area near Rodi Garganico and in the certain sites between Rodi Garganico and Peschici. However, in these areas, bioconstructions are exclusively present in the form of thin concretions, with a patchy distribution.

\subsection{Extension of the reef and temporal changes in its structure}

The large S. spinulosa reef occurring near Torre Mileto $\left(41^{\circ} 56^{\prime}\right.$ $00^{\prime \prime} \mathrm{N} ; 1^{\circ} 37^{\prime} 00^{\prime \prime} \mathrm{E}$ ) (Fig. 1a) appeared as a mix of outcrops of S. spinulosa of different size, from a few $\mathrm{cm}$ up to about $30 \mathrm{~m}^{2}$ in area. Bioconstructions, in the form of dense aggregations of mounds, hummocks and barriers, protruded above the surrounding hard and sandy substrate and extended over an area of about $10,000 \mathrm{~m}^{2}$ (Fig. 1b). They appeared around $2 \mathrm{~m}$ from the coast line, at a depth of $20 \mathrm{~cm}$, and completely disappeared at a depth of $290 \mathrm{~cm}$ (around $40 \mathrm{~m}$ from the coast line). Around their low and deep range of distribution the bioconstructions appeared as discrete crusts some $\mathrm{cm}$ thick, progressively increasing in size to form true reefs around $130-160 \mathrm{~cm}$ of depth. Fig. 2 shows some underwater images of the reef to report typical morphologies of the bioconstruction in different development periods.

According to the thickness measures, the reef showed its elevation, rising above the substrate from 10 to $60 \mathrm{~cm}$. Table 1 shows the temporal changes of the reef development, with a maximum value in October 2012, and a minimum in February 2013 (about 60 and $13 \mathrm{~cm}$ in thickness, respectively). The low elevation recorded in February coincided with the lowest values in Sabellaria density. On the other hand, the reef with the highest elevation occurred in October, when the highest values of individuals and tube density were recorded (Table 1 ). Moreover, the highest value of the mean diameter of the Sabellaria tubes was measured in February, while in October and June lower values were recorded (minimum value in June 2013). This is also shown by the image analysis of the thin sections of the reef, these during October highlighting dense contiguity of both narrow and broad tubes. By contrast, in February the tubes were wider in diameter and more scattered, with several grains of sediment interposed, as well as some tubes being unoccupied and subsequently filled with sand (Fig. 3).

\subsection{Associated fauna}

A total of 99 taxa was found, with a mean abundance value of 1035 individuals of associated fauna (excluding Sabellaria); the list of the species is shown in Table 2. The associated fauna with the reef mainly consisted of molluscs (75.1\%), crustaceans (19.5\%) and polychaetes (3\%). Crustaceans and polychaetes reached the highest species richness (36 and 31 species respectively), followed by molluscs ( 26 species), echinoderms with 3 species and anthozoans, sipunculans and pycnogonids with one species only. Sessile fauna included some gregarious bivalves (Mytilus galloprovincialis and Striarca lactea), even though the majority of the recorded species consisted of non-colonial forms. Sessile species dominated in terms of abundance values, but the highest number of species were vagile and sedentary forms.

Species richness was higher in October and especially in February, while the highest abundance values were recorded in June and secondly in February. Diversity was higher in October and February, in October evenness also reached the highest value, while eveness reached the lower values in February (Fig. 4). Significant differences were recorded in all these biotic parameter among samples times (Table 3).

M. galloprovincialis, Monocorophium sextone, Perforatus perforatus, Apseudes holthuisi, Cyathura carinata, Hiatella arctica and H. rugosa accounted for $54.2 \%$ of the total abundance. Among polychaetes, Nereididae, Syllidae and the species Lumbrinereis coccinea were represented by many individuals, while the species of the other families had very few individuals. The most abundant crustaceans found included Maera inaequipes, Jassa marmorata, Elasmopus brasiliensis. Among molluscs, M. galloprovincialis alone comprised up to $43.5 \%$ of the total abundance. Apart from the relatively abundant gastropods Bittium spp, and bivalves (Striarca lactea, Lentidium mediterraneum, Irus irus), few individuals of other species were found. Regarding the faunal composition, several species were also recurring on the reef, e.g. the polychaetes Notomastus latericeus, $N$. lineatus, Nereiphylla rubiginosa, the sipunculid Golphingia vulgaris, commonly found on mud-sandy sediments, the molluscs Nassarius incrassatus, Venerupis corrugata and the polychaete Galathowenia oculata typical of sandy bottoms and some interstitial animals such as the Syllidae Parahelersia ferrugina and Syllis corallicola. Other species recurring on the reef, such as A. nitescens, L. seticaudata, M. linearesi, P. longimana, P. platycheles, which are usual inhabitants of rocky and algal substrates mixed with sandy bottoms. The wide variation in the abundance values of the fauna associated with the reef was mainly due to the peaks of M. galloprovincialis and Hiatella spp. Other species that contributed most to total abundance were $P$. perforatus, usually inhabiting hard bottoms, and C. carinata, A. holthuisi, M. sextone, L. mediterraneus, typically linked to sediment. When these species were absent, no other dominant species replaced them, and the benthic assemblage consisted of few individuals for each species.

The nMDS plot (Fig. 5) showed the macrofaunal assemblages of October clearly separated from those of the other months on the left of the model, where the assemblages of February and June are placed close to one another on the right. The ordination plot 


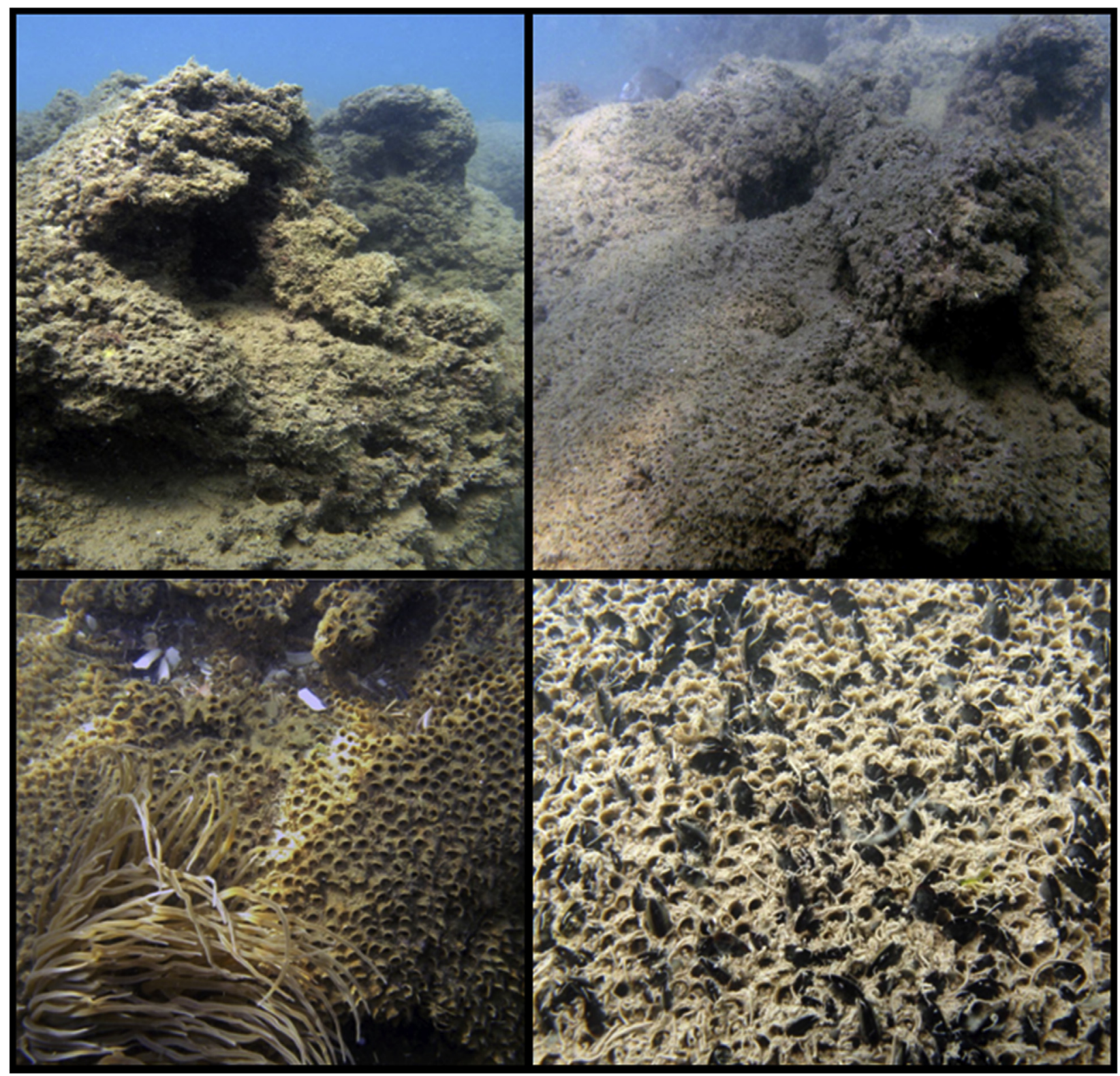

Fig. 2. Underwater images of the $S$. spinulosa reef at Torre Mileto (Adriatic coast of Apulia).

Above: Sabellaria reef during its complete development; below: details of the reefs, with the overgrowth of serpulids and Mytilus galloprovincialis in the right.

Table 1

Temporal changes in some reef features (mean $\pm \mathrm{SE}$ ).

\begin{tabular}{|c|c|c|c|}
\hline Period & Mean Reef thickness $(\mathrm{cm})$ & Mean diameter of Sabellaria tubes $(\mu \mathrm{m})$ & $\mathrm{N}^{\circ}$ Sabellaria tubes $\left(1 \mathrm{~m}^{2}\right)$ \\
\hline April 2012 & $21.4 \pm 4.7$ & $1322.60 \pm 17.2$ & $25,175 \pm 900$ \\
\hline October 2012 & $60.0 \pm 9.2$ & $1203.71 \pm 49.5$ & $36,975 \pm 900$ \\
\hline February 2013 & $13.3 \pm 11.2$ & $1427.25 \pm 28.3$ & $18,875 \pm 800$ \\
\hline June 2013 & $31.8 \pm 10.9$ & $1124.25 \pm 41.9$ & $28,325 \pm 1.000$ \\
\hline
\end{tabular}

obtained had a low stress level (0.046), indicating the good quality of the result.

The Analysis of Similarity test (ANOSIM) assessed significant dissimilarity in macrofaunal assemblages among the four groups of samples (times): Global $\mathrm{R}=0.91, \mathrm{p}=0.0002$. The analysis of Similarity Percentage (SIMPER) revealed twelve taxa to be primarily responsible for the overall dissimilarity (90\%) observed between times and included the mollusc $M$. galloprovincialis which contributed most to the average dissimilarity between the four months, B. reticulatum, C. carinata, A. holthuisi, $M$. sextone which contributed $2-4 \%$, $P$. perforatus, $M$. inaequipes, $H$. arctica, $N$. perivisceralis, S. garciai and N. latericeus which contributed between 0.8 and $1.1 \%$

From the ecological point of view, the S. spinulosa reef was characterized by an unusual macrofaunal assemblage. Most species are typical of hard substrate with algal cover: they mainly included 


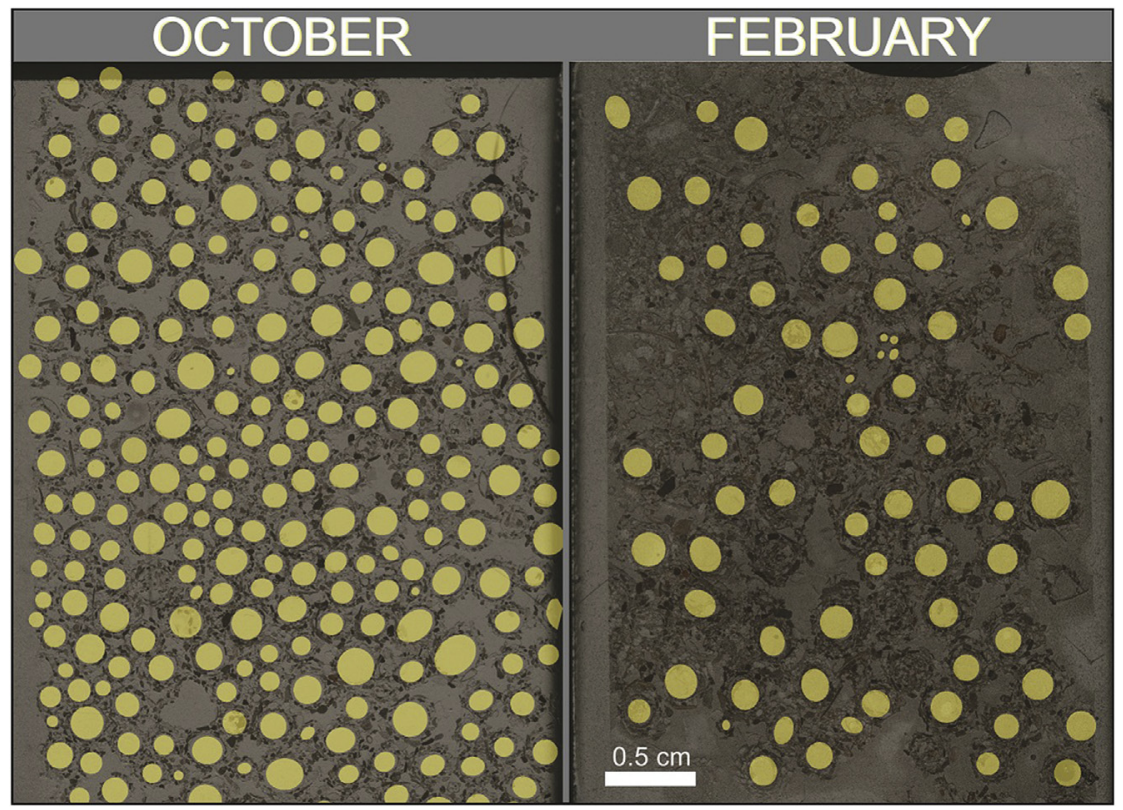

Fig. 3. Thin sections of the reef Digitized thin sections of samples of the Sabellaria spinulosa reef at two different times.

motile species, especially polychaetes (Nereis perivisceralis, $N$. falsa, N. zonata, Syllis corallicola, S. garciai, Lumbrinereis coccinea), crustaceans (E. brasiliensis, M. inaequipes, A. holthuisi), together with two species of gastropods (Bittium reticulatum and $B$. latreilli). Other species are typically associated with sandy bottoms and sediment trapped at the basal layer of the algal cover, namely the crustaceans M. sextone, C. carinata, L. savignyi, the decapods Alpheus dentipes, Athanas nitescens, Pilumnus hirtellus and the ophiurid Amphipholis squamata. Sessile species on hard bottom, H. arctica, H. rugosa, Irus irus, S. lactea, M. galloprovincialis, $P$. perforatus, the borer $P$. lithophaga, and some soft-bottom species, namely the polychaetes Notomastus latericeus, $N$. lineatus and the bivalve Lentidium mediterraneum, were also found on the reef.

The regression analysis (Fig. 6) showed the relationships between faunal biotic variables (species richness, abundance, Diversity, eveness) and the reef developmental stage measures (density and tube diameter of Sabellaria). A high abundance of associated fauna was observed corresponding to the minimal thickness of the reef and the low density of large individuals of Sabellaria (Table 1, Fig. 4); in contrast, there was a low abundance of associated species when the reef is developed and reached high density of small individuals of Sabellaria (negative regression between density of Sabellaria and abundance of fauna, Fig. 6).

\section{Discussion}

This is the first study examining the biotic characteristics and dynamics of the biogenic concretion produced by this worm in the Mediterranean Sea, as well as the associated biodiversity. Indeed, hitherto this species was known in Mediterranean area only to form thin sheets, small globular formations or hummocks, without evolving into reef platforms. By contrast, along the length of the coast of Apulia here investigated, the morphological and biological measures, such as the elevation of the bioconstruction, individual density and the distribution of consolidated tubes lead us to consider this S. spinulosa aggregation as a true reef, its extent and profile being coherent with the definition of 'reef provided by the Manual of European Union Habitats (EUR 25). Usually dense aggregations of over $4500-12,000$ individuals per $\mathrm{m}^{2}$ were reported for reefs built by this species in North Atlantic coasts, with a maximum density value being about 12,000 individuals $/ \mathrm{m}^{2}$ (Limpenny et al., 2010). In contrast, in the present study S. spinulosa tube density reached the extraordinary high value of about 37,000 individuals $/ \mathrm{m}^{2}$ during October. However, the reef underwent rapid changes over time, varying its morphology from thin crusts up to $60 \mathrm{~cm}$ in thickness in a few months. This process is well studied for S. alveolata where different phases can be observed, i.e. settlement, growth, stagnation and destruction (Gruet, 1986), corresponding to a variable density of Sabellaria tubes in time (Wilson, 1971; Gruet, 1986; Dubois et al., 2002; Firth et al., 2015).

In our study a condition of scarce development of the reef, corresponding to the destruction phase, prevailed during February, probably due to the mechanical disturbance caused by storms, frequent during this time. In contrast, the maximum reef thickness occurred in October, as results of peak in the growing phase. The diameters of the tubes were consistent with the presence of only large tube openings of adult specimens in February, and the cooccurrence of both juveniles and adults, with narrow tubes for juveniles and broad tubes for adult individuals in October. In this month the reef was characterized by both the highest values of specimens and tube density, and lower diameters of the Sabellaria tubes. Recruitment phases are characterized by a larger variability of the tube diameters, higher density of tubes and by the absence of abandoned tubes. In April and June the increase in the individual density coupled with the smallest diameters of the tubes indicate the beginning of the growing phase in spring and its continuing in summer, suggesting a possible settlement phase in early spring. The occurrence of tubes filled by sands is a key element, which only characterizes the reef during degradation. These 'abandoned' tubes are associated with higher diameters of the tubes but lower diameter variability.

Morphological changes observed in the reef are supported by laboratory observation carried out during a previous experimental study (Lezzi et al., 2015) which reported the species as a fast growing annual form reproducing once in its life, with a prolonged spring-summer reproductive period, and the occurrence of small individuals in October. Therefore, the time of growth, tube building and aggregation observed in laboratory conditions are consistent 
Table 2

List of species found in the investigated Sabellaria spinulosa reef. The asterisks mark a semiquantitative classification of the species associated to the reef according to their abundances $\left(^{*}=1-10\right.$ individuals; $^{* *}=11-100$ individuals; $^{* * *}>100$ individuals).

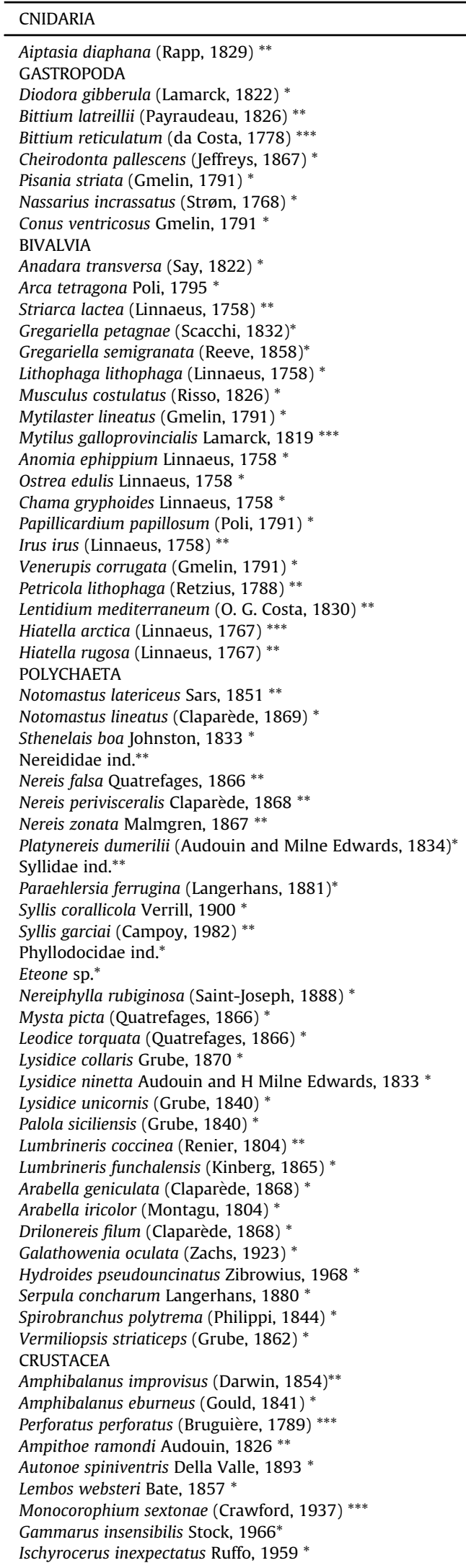

Table 2 (continued)

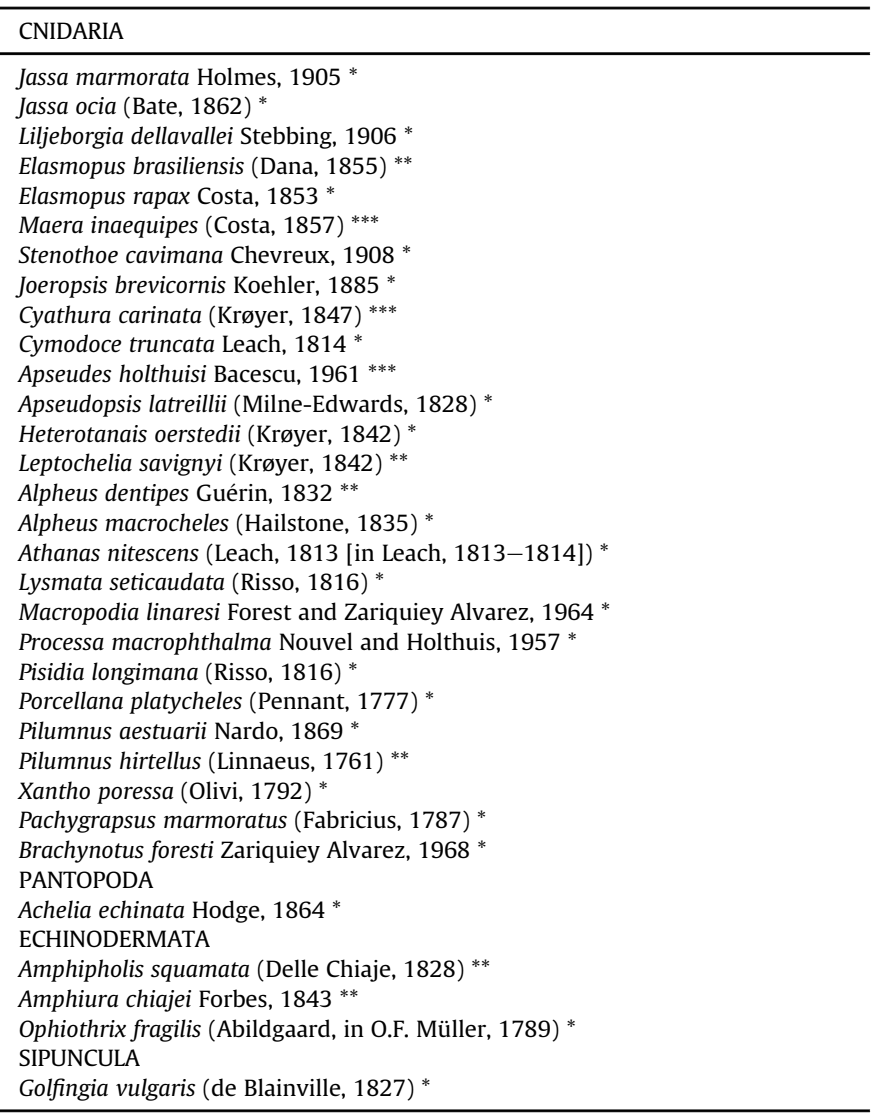

with the Sabellaria densities found in the field increasing from April to June.

An unusual macrofaunal assemblage was found associated with the reef. It was highly complex and diverse with most of the species typical of hard substrate with algal cover and others typically associated with sandy bottoms and sediment trapped at the basal layer of the algal cover.

The observed species composition and abundance values reflect the reef complexity and highlight its important role within the coastal environment. This is because the ex novo creation of a colonizable hard substrate by Sabellaria can support a richer assemblage. The larger number of hard bottom species on the reef is in line with the reef architectural complexity of many animals finding a suitable substrate on the three-dimensional surface exposed by the $S$. spinulosa tubes. At the same time, the sediment trapped among the reef interstices and crevices supports colonization by soft bottom and interstitial species. Therefore, the results here clearly show the S. spinulosa capability in modifying, maintaining and creating habitat, as already observed in various studies involving the congeneric species S. alveolata (Gruet, 1971; Porras et al., 1996). In addition its probable ability in controlling resources used by other species (Rigolet et al., 2014) qualifies such a species for the role of a 'physical ecosystem engineer species' (sensu Jones et al., 1997).

As the regression analysis highlighted, development of associated fauna follows the cycle of the reef suggesting that the species can affect either positively or negatively the settlement of other species and so supporting the importance of the reef developmental status on the abundance and diversity of the associated fauna. A facilitating role can be highlighted in spring, when a high settlement rate is generally known in the Mediterranean area; 

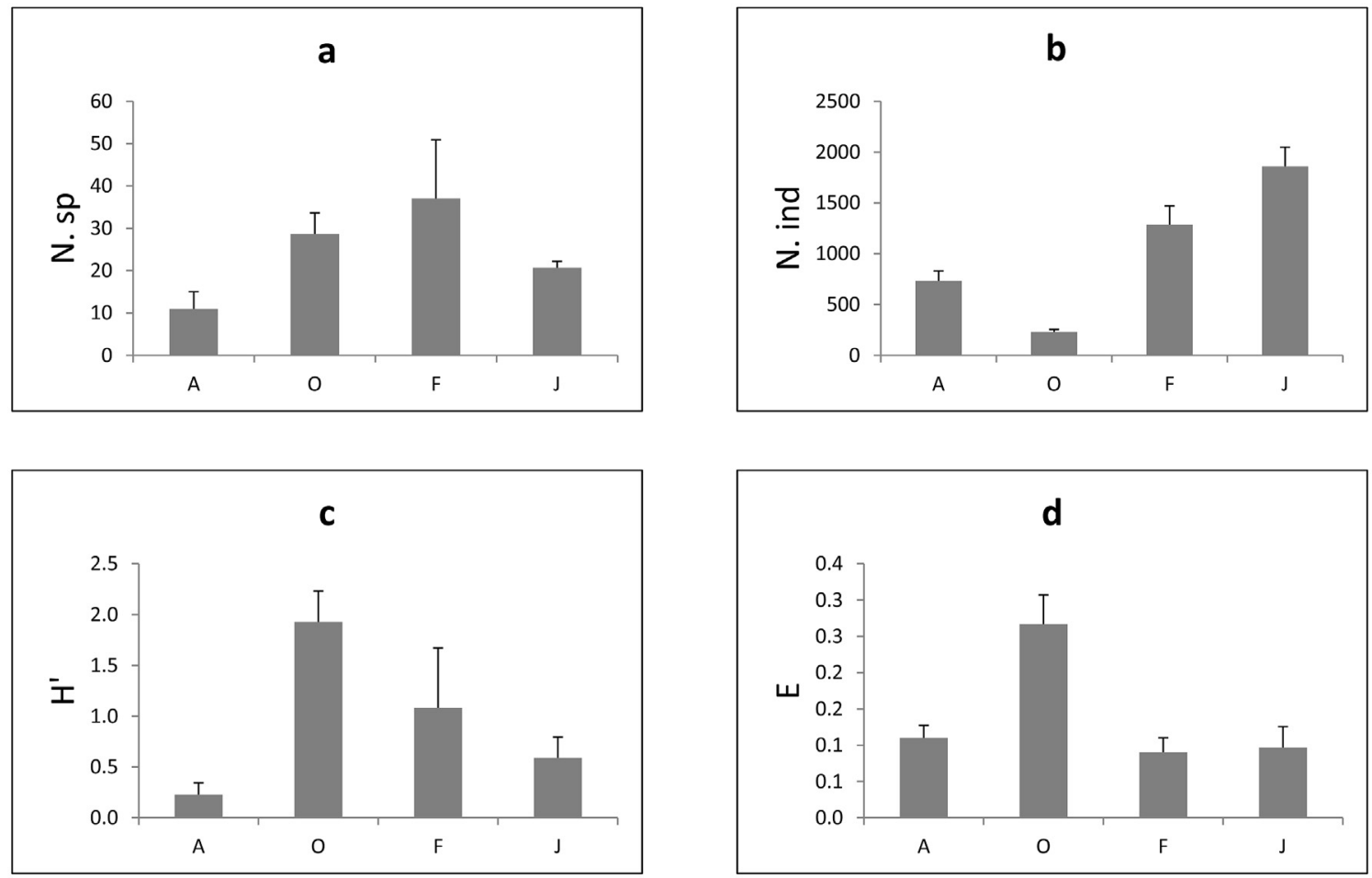

Fig. 4. Temporal trend of a) species richness (N. sp), b) abundance (N. ind), c) Diversity $\left(\mathrm{H}^{\prime}\right)$ and d) Evenness (E) (mean $\pm \mathrm{SE}$ ). Sampling date: $A=$ April 2012, O = October 2012, F = February 2013, J = June 2013.

Table 3

One-way ANOVA for differences in biotic parameters of macrobenthic assemblages between times (months) a) Number of species, b) Abundance, c) Diversity, d) Evenness.

\begin{tabular}{|c|c|c|c|c|}
\hline \multicolumn{5}{|l|}{ a) } \\
\hline & df & Mean square & $\mathrm{F}$ & $\mathrm{p}$ \\
\hline Between & 3 & 354 & 6.669 & 0.01 \\
\hline Within & 8 & 53.08 & & \\
\hline Total & 11 & & & \\
\hline \multicolumn{5}{|l|}{ b) } \\
\hline & df & Mean square & $\mathrm{F}$ & $\mathrm{p}$ \\
\hline Between & 3 & $1.48 \mathrm{E} 06$ & 73.14 & 3.7E-06 \\
\hline Within & 8 & $20,247.4$ & & \\
\hline Total & 11 & & & \\
\hline \multicolumn{5}{|l|}{ c) } \\
\hline & df & Mean square & $\mathrm{F}$ & $\mathrm{p}$ \\
\hline Between & 3 & 1.624 & 13.18 & 0.0018 \\
\hline Within & 8 & 0.123 & & \\
\hline Total & 11 & & & \\
\hline \multicolumn{5}{|l|}{ d) } \\
\hline & df & Mean square & $\mathrm{F}$ & $\mathrm{p}$ \\
\hline Between & 3 & 0.021 & 26.93 & 0.00015 \\
\hline Within & 8 & 0.0008 & & \\
\hline Total & 11 & & & \\
\hline
\end{tabular}

during this period the reef is present as a complex substrate but not so densely inhabited by the Sabellaria specimens which could compete for settlement with the other benthic species. In contrast, together with the reef peak, distinguished as 'growth phase' (according to Gruet, 1986), we can hypothesize that competitive behavior by adult Sabellaria specimens prevents other species colonizing the space and competing for resources. The described

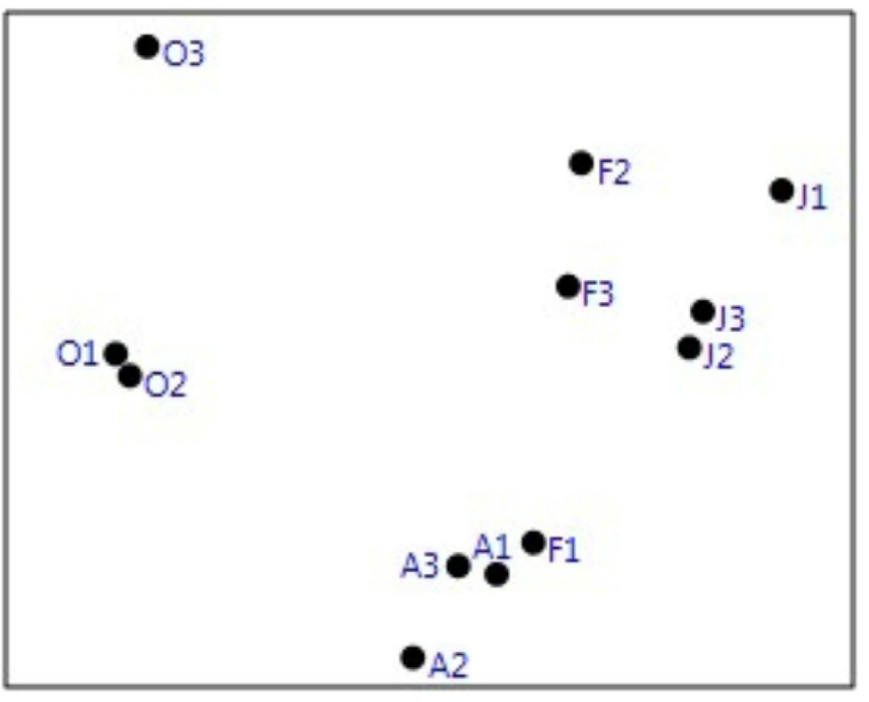

Fig. 5. Non-metric multidimensional scaling (n-MDS) ordination model on the BrayCurtis similarity matrix for the abundance of benthic associated fauna of the Sabellaria reef at the four times investigated; $A=$ April 2012, $\mathrm{O}=$ October 2012, F=February 2013 , J = June 2013 (stress $=0.046$ ). In the plot the centroid resulting from the mean of the replicates are showed.

trend from October to June is relative to the reef development deriving from recruitment of the year 2013. On the other hand, the biotic data of the associated fauna in April 2012 are referred to the previous cycle of reef development involving the recruitment of 2012 and showed, however, similar to the values of species richness and diversity measured in July 2013. The distinction between the observed phases in the associated fauna was confirmed by the MDS analysis, which highlighted the clear separation of the cluster of 

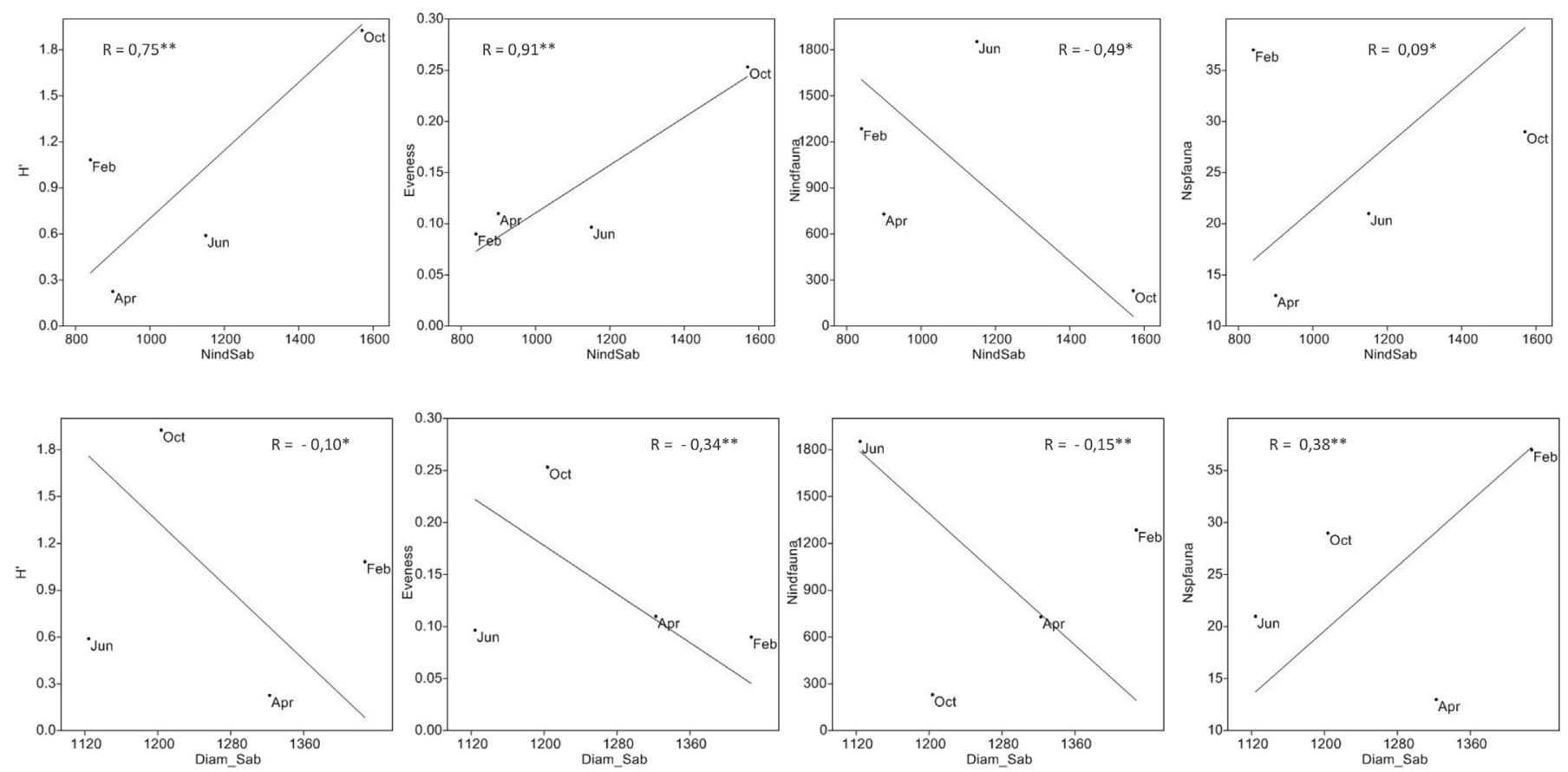

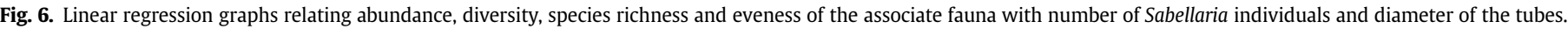
Correlation coefficients $\mathrm{R}$ with the associated $\mathrm{p}$ are reported in the graphs $\left({ }^{*} \mathrm{p}<0,01 ;{ }^{* *} \mathrm{p}<0,001\right.$ ).

October samples from the rest, with the samples of April 2012 located in intermediate position closer to the samples of February and June. The rather high values of Sabellaria tube density and reef thickness create suitable space for the settlement of young individuals either of the Sabellaria itself or of other sessile species, such as M. galloprovincialis and Hiatella spp., these latter contributing most to the peaks in the associated fauna abundance. $M$. galloprovincialis proved to be the species that contributed most to the abundance of the associated fauna. However, notwithstanding the very high number of individuals of such species found on the reef, the benthic assemblages can in no way be considered as 'mussel beds', due to the very young stage of the mussels. In the light of the conservation status of the reef, this fact is not a good sign; in fact in other areas, e.g. the French north coast and UK west coast (Desroy et al., 2011; Egerton, 2014), Sabellaria bioconstructions are cyclically replaced by $M$. galloprovincialis beds, although this phenomenon was not observed during our study.

The temporal trend in the structure of the associated assemblages differing during the phases of reef development, with higher values of abundance of associated fauna during the destruction phase and lower values during the reef recovery phase, is a phenomenon already observed for S. alveolata reef from Mediterranean coasts (La Porta and Nicoletti, 2009). A similar inverse relationship between reef growth and organization of the associated fauna has also been highlighted for the $S$. alveolata reef from the Gulf of Valencia along Spanish Mediterranean coasts (Porras et al., 1996). On the other hand, Dubois et al. (2006) showed that in the case of S. alveolata reefs the effect of some epibionts, such as oysters and green algae, is to reduce the successful recruitment of the Sabellaria, in contrast with the increased colonization phase by associated fauna.

As a whole, S. spinulosa directly transforms the habitat via growth and development of the tube aggregation and remains part of the bioconstructed habitat, revealing an endogenous process, hence its role as 'autogenic engineer' (Jones et al., 1997). In fact, the reef increases free spaces and microhabitats both among the tubes inhabited by the Sabellaria and within the empty tubes, providing an appropriate sediment trap. These diverse conditions of the substrate stimulate the settlement of other invertebrate larvae and offer a refuge for the development of benthic community. Many small species depend on the tube-building Sabellaria habitat structuring ability. The reef greatly increases the surface heterogeneity of the bottom and enlarges the landscape complexity, thus characterizing it as an important hot-spot of biodiversity. More specifically, no abundant species were exclusive to the $S$. spinulosa reef, revealing that the reef was strongly integrated into the local coastal ecosystem, albeit the analysis of taxa based on their substrate affinity revealed highly diverse and very unique benthic assemblages. However, a recent study carried out in the Mediterranean area (Schimmenti et al., 2016) suggested that at least one species, the Polychaete Eulalia ornata, should be preferentially associated to a sabellarid reef. In addition, such tubebuilding polychaetes play an important role in enhancing the biodiversity of rare invertebrate species. The all-too-often neglected role of the latter in the ecosystem was thoroughly reappraised and analyzed, highlighting that rarity can represent the source of variation which marine environments need to tackle environmental changes (Boero, 1994; Bianchi et al., 2014).

The habitat-structuring ability by high density aggregations of some polychaete species, such as Sabellaria spp. and also Lanice conchilega, has been demonstrated in some Atlantic regions (Callaway et al., 2010; Desroy et al., 2011; Godet et al., 2011). In this study, we show also that in the Mediterranean area S. spinulosa may trap and concentrate sediment particles, so modifying the physical and the biological compartments along the investigated Apulian coast. From the physical viewpoint, the structuring effect of the studied Sabellaria reef on the coastal area off the Gargano Promontory has been reported by Lisco et al. (2017), who highlighted the role of the reef as a physical barrier for storm waves and long-shore currents and as a temporary storage of sandy sediments, so mitigating coastal erosion. 


\section{Conclusions}

Although only some aspects of the temporal variability of the reef are presented here, they can be considered a starting point for investigating its persistence and temporal stability for conservation of these important habitats which, as already pointed out, in contrast to the North Atlantic scenario, is listed as 'data deficient'. Further long-term studies are required to analyze the longevity and stability of this biogenic habitat over time. It will also be necessary to investigate the influence of external factors such as winter storms which reduce the biogenic structural thickness, together with impact the recruitment of juvenile mussels which could extensively settle onto the reef in the future. Thus the present work paves the way for further studies necessary for assessing the reef's state of health and evaluating policies based on its conservation status, these aspects being highly relevant to the aims of the Habitat Directive.

\section{Acknowledgements}

We wish to acknowledge Marcello Giorgi (University of Rome "Tor Vergata") for his technical assistance during laboratory experiments and analysis of data. This study benefited from funding through the BIOMAP project (P.O. FESR 2007/2013, Puglia Region, Italy) and by the Italian Ministry of Education, University and Research (PRIN 2010-2011).

\section{References}

Bianchi, C.N., Morri, C., Pronzato, R., 2014. The other side of rarity: recent habitat expansion and increased abundance of the horny sponge Ircinia retidermata (Demospongiae: Dictyoceratida) in the southeast Aegean. Italian J. Zoology 81, $564-570$.

Boero, F., 1994. Fluctuations and variations and variations in coastal marine environments. PSZN I Mar. Ecol. 15, 3-25.

Callaway, R., Desroy, N., Dubois, S.F., Fournier, J. Frost, M., Godet, L., Hendrick, V.J., Rabaut, M., 2010. Ephemeral bio-engineers or reef-building Polychaetes: how stable are aggregations of the tube worm Lanice conchilega (Pallas, 1766)? Integr. Comp. Biol. 50, 237-250.

Clarke, K.R., Warwick, R.M., 2001. Changes in Marine Communities: an Approach to Statistical Analysis and Interpretation, second ed. Primer-E LTD, Plymouth, UK.

Cole, V.J., Chapman, M.G., 2007. Patterns of distribution of annelids: taxonomic and spatial inconsistencies between two biogeographic provinces and across multiple spatial scales. Mar. Ecol. Prog. Ser. 345, 235-241.

Delbono, I., Bianchi, C.N., Morri, C., 2003. Le biocostruzioni di Sabellaria alveolata come indicatori ambientali: area costiera fra Chiavari e Sestri Levante. In: Ferretti, O. (Ed.), Studi per la creazione di strumenti di gestione costiera: Golfo del Tigullio, La Spezia, pp. 130-140. ENEA, Centro Ricerche Ambiente Marino.

Desroy, N., Dubois, S.F., Fournier, J., Ricquiers, L., Le Mao, P., Guerin, L., Gerla, D. Rougerie, M., Legendre, A., 2011. The conservation status of Sabellaria alveolata (L.) (Polychaeta: Sabellariidae) reefs in the Bay of Mont-Saint-Michel. Aquatic Conservation Mar. Freshw. Ecosyst. 21, 462-471.

Dubois, S., Retière, C., Olivier, F. 2002. Biodiversity associated with Sabellaria alveolata (Polychaeta: Sabellariidae) reefs: effects of human disturbances. J. Mar. Biol. Assoc. UK. 82, 817-826.

Dubois, S., Commito, J.A., Olivier, F., Retière, C., 2006. Effects of epibionts on Sabellaria alveolata (L.) biogenic reefs and their associated fauna in the Bay of Mont Saint-Michel. Estuar. Coast. Shelf Sci. 68, 635-646.

Egerton, S., 2014. Distribution Mapping and Health Assessment of Honeycomb Worm, Sebellaria Alveolata, Reefs on Heysham Flat, Lancashire (Report to the North Western Inshore Fisheries and Conservation Autority).

Firth, L.B., Mieszkowska, N., Grant, L.M., Bush, L.E., Davies, A.J., Frost, M.T., Moschella, P.S., Burrows, M.T., Cunningham, P.N., Dye, S.R., Hawkins, S.J., 2015 Historical comparisons reveal multiple drivers of decadal change of an ecosystem engineer at the range edge. Ecol. Evol. 5 (15), 3210-3222.

Fournier, J., 2013. Bioconstructions d'annélides polychètes. Complexité des niveaux d'organisation de l'organisme à l'écosystème (Synthese scientifique Institut France: Universitaire Européen de la Mer. CNRS).

Gallicchio, S., Moretti, M., Spalluto, L., Angelini, S., 2014. Geology of the middle and upper Pleistocene marine and continental terraces of the northern Tavoliere di Puglia plain (Apulia, southern Italy). J. Maps 10, 569-575.

Gibb, N., Tillin, H.M., Pearce, B., Tyler-Walters, H., 2014. Assessing the Sensitivity of Sabellaria Spinulosa to Pressures Associated with Marine Activities. JNCC report No. 504 , p. 67.

Gioia, D., Gallicchio, S., Moretti, M., Schiattarella, M., 2014. Landscape response to tectonic and climatic forcing in the foredeep of the southern Apennines, Italy: insights from Quaternary stratigraphy, quantitative geomorphic analysis, and denudation rate proxies. Earth Surf. Process. Landforms 39, 814-835.

Giordani Soika, A., 1956. Scogliera pseudocorallina intercotidale di Sabellaria alveolata (L.) delle coste del Lazio (Ann. Polych.). Boll. del Mus. civico Storia Nat. Venezia 9, 11-14.

Godet, L., Fournier, J., Jaffré, M., Desroy, N., 2011. Influence of stability and fragmentation of a worm-reef on benthic macrofauna. Estuar. Coast. Shelf Sci. 92, $472-479$.

Gruet, Y., 1971. Morphologie, croissance et faune associée des récifs de Sabellaria alveolata (Linné) de la Bernerie-en-Retz (Loire Atlantique). Tethys 3, 321-380.

Gruet, Y., Bodeur, Y., 1997. Les récifes d'Hermelles. In: Dauvin, J.C. (Ed.), Les biocénes marines et littorales françes des côtes Atlantiques, Manche et Mer du Nord, synthèse, menaces et perspectives. Service du Patrimoine Naturel/IEGB/MNHN, Paris, pp. 168-176.

Gruet, Y., 1986. Spatio-temporal changes of Sabellarian reef built by the sedentary polychaete Sabellaria alveolata (Linné). PSZN I Mar. Ecol. 7, 303-319.

Gubbay, S., Sanders, N., Haynes, T., Janssen, J.R., Rodwell, J.A.M., Nieto, M., Garcia Criado, A., Beal, S., Borg, J., Kennedy, M., Micu, D., Otero, M., Saunders, G., Calix, M., 2016. European Red List of Habitats. Part 1. Marine Habitats. European Union Publication Offices. http://forum.eionet.europa.eu/european-red-listhabitats/library.

Hammer, Ø., Harper, D.A.T., Ryan, P.D., 2001. PAST: Paleontological Statistics software Package for education and data analysis. Palaeontol. Electron. 4 (1), 1-9.

Hendrick, V.J., Foster-Smith, R.L., 2006. Sabellaria spinulosa reef: a scoring system for evaluating reefiness in the context of the Habitats Directive. J. Mar. Biol. Assoc. UK. 86, 665-677.

Holt, T.J., Rees, E.I., Hawkins, S.J., Seed, R., 1998. Biogenic Reefs. An Overview of Dynamic and Sensitivity Characteristics for Conservation Management of Marine SACs. Scottish Association for Marine Science, UK (UK Marine SACs Project).

Jones, C.G., Lawton, J.H., Shachak, M., 1997. Positive and negative effects of organisms as physical ecosystem engineers. Ecology 78, 1946-1957.

La Porta, B., Nicoletti, L., 2009. Sabellaria alveolata (Linnaeus) reefs in the central Tyrrhenian Sea (Italy) and associated polychaete fauna. Zoosymposia 2. 527-536.

Lezzi, M., Cardone, F., Mikac, B., Giangrande, A., 2015. Variation and ontogenetic changes of opercular paleae in a population of Sabellaria spinulosa (Polychaeta: Sabellariidae) from the South Adriatic Sea, with remarks on larval development. Sci. Mar. 79, 1-14.

Limpenny, D.S., Foster-Smith, R.L., Edwards, T.M., Hendrick, V.J., Diesing, M., Eggleton, J.D., Meadows, V.J., Crutchfield, Z., Pfeifer, S., Reach, I.S., 2010. Best Methods for Identifying and Evaluating Sabellaria Spinulosa and Cobble Reef. Joint Nature Conservation Committee, Peterborough, UK. Aggregate Levy Sustainability Fund Project MAL0008.

Lisco, S., Moretti, M., Moretti, V., Cardone, F., Corriero, G., Longo, C., 2017. Sedimentological features of Sabellaria spinulosa biocontructions. Mar. Petroleum Geol. 87, 203-212.

Mettam, C., 1992. The influence of Sabellaria reef on Sublittoral community structure. Polych. Res. Newsl. 14, 3.

Moretti, M., Gallicchio, S., Spalluto, 1., Ciaranfi, N., Pieri, P., 2010. Evoluzione geologica del settore settentrionale del Tavoliere di Puglia (Italia meridionale) nel Pleistocene medio e superiore. Alp. Mediterr. Quat. 23 (2), 181-197.

Molinier, R., Picard, J., 1953. Notes biologiques à propos d'un voyage d'étude sur les côtes de Sicile. Ann. l'Institut Océanogr. 28, 164-187.

Naylor, L.A., Viles, H.A., 2000. A temperate reef builder: an evaluation of the growth, morphology and composition of Sabellaria alveolata (L.) colonies on carbonate platforms in South Wales. In: Insalaco, E., Skelton, P.W., Palmer, T.J. (Eds.), Carbonate Platform Systems: Components and Interactions, 178. Geological Society, Special Publications, London, pp. 9-19.

Nicoletti, L., Lattanzi, L., La Porta, B., La Valle, P., Gambi, M.C., Tomassetti, P., Tucci, P., Chimenz Gusso, C., 2001. Biocostruzioni a Sabellaria delle coste del Lazio (Tirreno Centrale). Biol. Mar. Mediterr. 8, 252-258.

OSPAR, 2008. Marine Biodiversity Monitoring and Assessment: Activities to Improve Synergies between EU Directives and International Conventions. OSPAR Monitoring and Assessment Series, 2008/357, p. 65.

Plicanti, A., Domínguez, R., Stanislas, F., Dubois, S., Bertocci, I., 2016. Human impacts on biogenic habitats: effects of experimental trampling on Sabellaria alveolata (Linnaeus, 1767) reefs. J. Exp. Mar. Biol. Ecol. 478, 34-44.

Porras, R., Bataller, J.V., Murgui, E., Torregrosa, M.T., 1996. Trophic structure and community composition of polychaetes inhabiting some Sabellaria alveolata (L.) reefs along the Valencia Gulf coast, western mediterranean. PSZN I Mar. Ecol. 17, 583-602.

Rigolet, C., Thiébaut, E., Dubois, S., 2014. Food web structures of subtidal benthic muddy habitats: evidence of microphytobenthos contribution supported by an engineer species. Mar. Ecol. Prog. Ser. 500, 25-41.

Schimmenti, E., Musco, L., Lo Brutto, S., Mikac, B., Nygren, A., Badalamenti, F., 2016. Mediterranean record of Eulalia ornata (Annelida, Phyllodocidae) corroborating its fidelity link with the Sabellaria alveolata reef habitat. Mediterr. Mar. Sci. 17 (2), 359-370.

Simeoni, U., Calderoni, G., Tessari, U., Mazzini, E., 1999. A new application of system theory to foredunes intervention strategies. J. Coast. Res. 15, 457-470.

Taramelli Rivosecchi, E., 1961. Osservazioni sulle biocenosi del banco a Sabellaria di Lavinio. Rendiconti dell'Accademia Naz. 40-41, 1-11.

Wilson, D.P., 1971. Sabellaria alveolata (L.) at Duckpool, north Cornwall. J. Mar. Biol. Assoc. UK. 51, 509-580. 